A Pécsi Tudományegyetem, Általános Orvostudományi Kar', a PTE KK Gyermekgyógyászati Klinika, Manuális Tanszék, Gyermeksebészeti Osztály² és a PTE KK Érsebészeti Klinika ${ }^{3}$ közleménye

\title{
Érsérüléssel szövődött supracondylaris humerus törések kezelése gyermekkorban
}

ILONKA ORSOLYA', DR. VAJDA PÉTER², DR. ARATÓ ENDRE³, DR. BENKŐ LÁSZLÓ, DR. JÓZSA GERGŐ²

\section{ÖSSZEFOGLALÁS}

A gyermekkori könyöktáji törések 60\%-át a supracondylaris humerus $(\mathrm{SCH})$ törések teszik ki, amelyek 95-98\%-ban extenziós típusúak és döntő többségük Baumann III-as típusú törés. A Baumann III-as típusú törések 8-10\%-a érsérüléssel szövődhet. A PTE KK, Gyermekklinika, Manuális Tanszék, Gyermeksebészeti Osztályán 2013 és 2018 között 46 gyermek kezelése történt Baumann III-as típusú SCH törés miatt. Jelen tanulmányban a szerzők a betegek nemek közti megoszlását, a sérülések évszaki előfordulását, a törések kialakulásának okait, a felmerülő érsérülés esetén a kezelés menetét és annak sikerességét vizsgálták. A nemek közötti megoszlás azonos volt. A törések leggyakrabban a meleg, száraz évszakok során fordultak elő, a leggyakoribb ok a magasból való esés volt. A 46 gyermekből 35 gyermekben a mútétet megelőzően az érintett végtag radialis pulzusa megtartott volt. További 11 gyermek esetében pulzuskvalitás eltérés volt észlelhető. A 35 gyermeknél, akiknél a pulzus a beavatkozást megelőzően jól tapintható volt, fedett repozíciót követően egy gyermeknél a radialis pulzus eltűnt. Érsérülés gyanúja miatt 12 gyermeknél történt nyílt feltárás. Négy gyermeknél az ér megtöretése, három gyermeknél az ér kompressziója, két esetben thrombus képződés, egy sérültnél az intima sérülése és egy-egy gyermeknél érspazmus, illetve teljes szakadás állt a pulzusdeficit hátterében. Megtartott radialis pulzus esetén, a törés kíméletes fedett repozíciója és $\mathrm{K}$-drótos túzés javasolt. Hiányzó pulzus, de megtartott kollaterális keringés mellett is az SCH törés kíméletes fedett repozíciója elvégezhető, azonban a retrospektív vizsgálatunk alapján a primer feltárás ilyen esetekben mindig mérlegelendő. Fehér, húvös tapintatú, pulzus nélküli kéz esetén, vagy ha a fedett repozíciót követően a végtag keringése rosszabbodik, nyílt feltárás mellett kell dönteni. Nyílt feltárást követően az ér ellátását az érsérülés típusa határozza meg.

\section{Kulcsszavak: $\quad$ Érsérülés; Gyermekkor; Humerus törés;}

\section{O. Ilonka, P. Vajda, E. Arató, L. Benkő, G. Józsa: The treatment of supracondylaer humeral} fracture associated with vessel injury in children

Supracondylaer humeral $(\mathrm{SCH})$ fractures represent the $60 \%$ of elbow fractures in children. The extension type fractures account for $95-98 \%$ of all SCH fractures. From which the majority are Baumann III type fractures. Twenty percent of Baumann III type $\mathrm{SCH}$ fractures associate with vessel injury. Between 2013 and 2018, 46 children were treated with Baumann III type supracondylaer humeral fracture at the Department of Pediatric of University of Pécs. The sex of the patients and seasonal distribution of the fractures, causes of fractures' development, the adequate treatment of the emerged vessel injuries, and its success were analysed. The distribution of sex was $50-50 \%$. Fractures were occurred more frequently during the warm and dry seasons. The most common cause of $\mathrm{SCH}$ humeral fracture was a fell from a considerable height. Out of 46 children, 35 were diagnosed with palpable radial pulse before the surgery, and 11 children were diagnosed with a different quality of radial pulse. After the closed reduction the radial pulse of 34 children recurred. The remaining 12/46 patients underwent an open reduction after the closed fracture reduction. In 4 cases, the angulation of the artery was found, 3 children were diagnosed with vessel compression. The circulation in 2 children's hand was obstructed by thrombosis, intima lesion 
was detected in one patient, and one child was diagnosed with arterial spasm and another with complete arterial rupture. In case of palpable pulse, closed reduction is suggested. In case of an absent radial pulse, but present collateral flow, the closed reduction could be done moderately. Based on our retrospective study, when the radial pulse is instable, an open reduction has to be performed. In accordance with these cases, a primary open reduction seems to be worth considering. In case of a white, cool, pulseless hand or worsening hand circulation after closed reduction, open reduction is always suggested. During the open reduction, treatment of the artery depends on the type of vessel injury.

Keywords: $\quad$ Blood vessels - Injuries; Child;

Humeral fractures - Complications/Therapy;

\section{BEVEZETÉS}

Gyermekkorban a könyökízület szalagjai lazábbak, ezért a nyújtott kézre történő esés során fiziológiás hiperextenzió alakul ki a könyökízületben. A hiperextenziókor az olecranon beékelődik a fossa olecraniba, és ha az ulna által közvetített feszítő erő elég nagy, extenziós típusú SCH törés jön létre. A gyermekkori könyöktáji törések $60 \%$-át az SCH törések teszik ki. Az SCH törések 95-98\%-ban extenziós, míg 2-5\%-ban flexiós típusúak (2).

Az extenziós típusú SCH törések csoportosítására több klasszifikációs rendszer is ismert (Baumann, AO, Gartland), ezek közül intézetünkben a Baumann-féle beosztást használjuk, ami az extenziós típusú töréseket három csoportba osztja (1. ábra).

A hármas típusú $\mathrm{SCH}$ töréseknél a sérülés bekövetkezésekor és a mútét közben, illetve azt követően is felléphetnek szövődmények (redislocatio, varus vagy valgus irányú deformitás, ér és idegsérülések stb.). Ezen töréstípus esetén a vascularis szövődmények gyakrabban fordulnak elő. Előfordulásuk gyakorisága egyenesen arányos a törés során bekövetkezett dislocatio mértékével. Az SCH törések 8-10\%-a társul érsérüléssel, a törések következtében leggyakrabban az arteria brachialis sérül $(5,8)$.

$A z$ érsérülés lehet: ruptúra, megtöretés, csavarodás, kompresszió, spasmus, intima sérülés, teljes szakadás vagy thrombosis $(2,3$, 6). Az érsérülések ellátását az érsérülés típusa határozza meg.

Az érsérülés nem megfelelő időben történő kezelése esetén súlyos következmények alakulhatnak ki. Az érsérüléssel szövődött gyermekkori $\mathrm{SCH}$ törések kezelése a nemzetközi és a hazai irodalomban csak szórványosan vizsgált. A vizsgálat célja az érsérülések hátterében álló okok, az érsérülések megjelenési formáinak és azok előfordulási gyakoriságának leírása és kezelési metódusaik ismertetése volt.
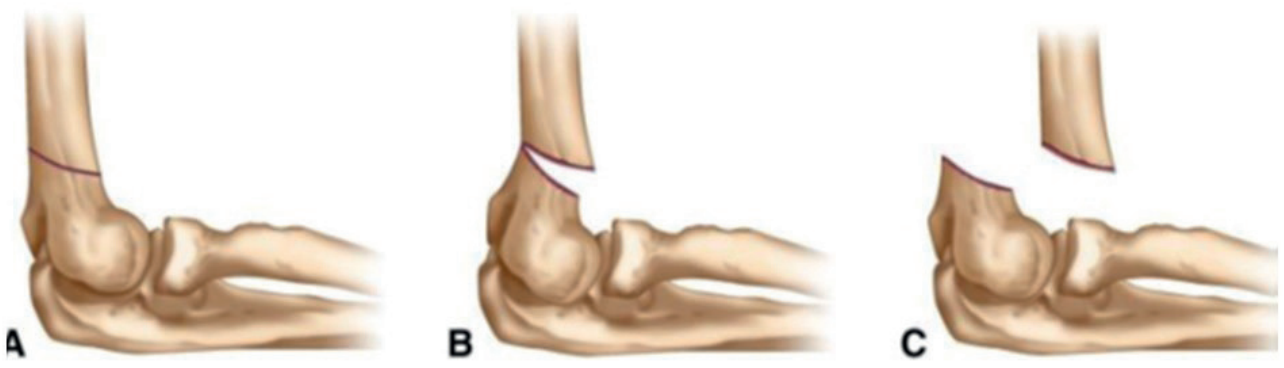

\section{1. ábra}

Az SCH törések Baumann szerinti klasszifikációja: Baumann I (A), Baumann II (B), Baumann III (C). (Forrás: Alton T. B., Werner S. E., Gee A. O.: Classifications in brief: The Gartland classification of supracondylar humerus fractures. Clin. Orthop. Relat. Res. 2015. 473. (2): 738-741.) 


\section{BETEGEK ÉS MÓDSZERTAN}

A retrospektív vizsgálatot a Pécsi Tudományegyetem, Klinikai Központ, Gyermekgyógyászati Klinika, Manuális Tanszékének Gyermeksebészeti Osztályán végeztük. A vizsgálat során a 2013. január 1. és 2018. december 31. között SCH törés miatt felvett gyermekek adatait elemeztük. Ebben az időszakban összesen 165 gyermeket láttunk el SCH törés miatt. A 165 eset közül 46 gyermeket operáltunk Baumann III-as típusú $\mathrm{SCH}$ töréssel. A 46 esetet, a mútétet megelőzően készült röntgenképek alapján választottuk ki. A gyermekek adatainak elemzése kapcsán nagy hangsúlyt fektettünk arra, hogy hány olyan Baumann III-as típusú SCH törést elszenvedett gyermek került felvételre, akiknél a fizikális vizsgálat vagy a törés ellátása során hiányzó radialis pulzust állapítottunk meg. Vizsgáltuk a Baumann III-as típusú SCH törések nemek közti, életkor szerinti és évszakos megoszlását, valamint kialakulásának okait (2-3. ábrák).

A pulzus kvalitása és a végtag színe alapján a sérült gyermekeket három csoportra osztottuk. Az első csoportba kerültek azok a gyermekek, akiknél a Baumann III-as típusú SCH törés utáni fizikális vizsgálat alapján megtartott radialis pulzust állapítottunk meg. A második csoportba a rózsaszín, pulzus nélküli kézzel (PPH-pink pulseless hand) felvett gyermekek, a harmadik csoportba a fehér, pulzus nélküli kézzel (WPH-white pulseless hand) felvett gyermekek kerültek. A nyílt feltárásra szorult, gyermekeknél vizsgáltuk az érsérülések típusait és azok mútéti megoldásait.

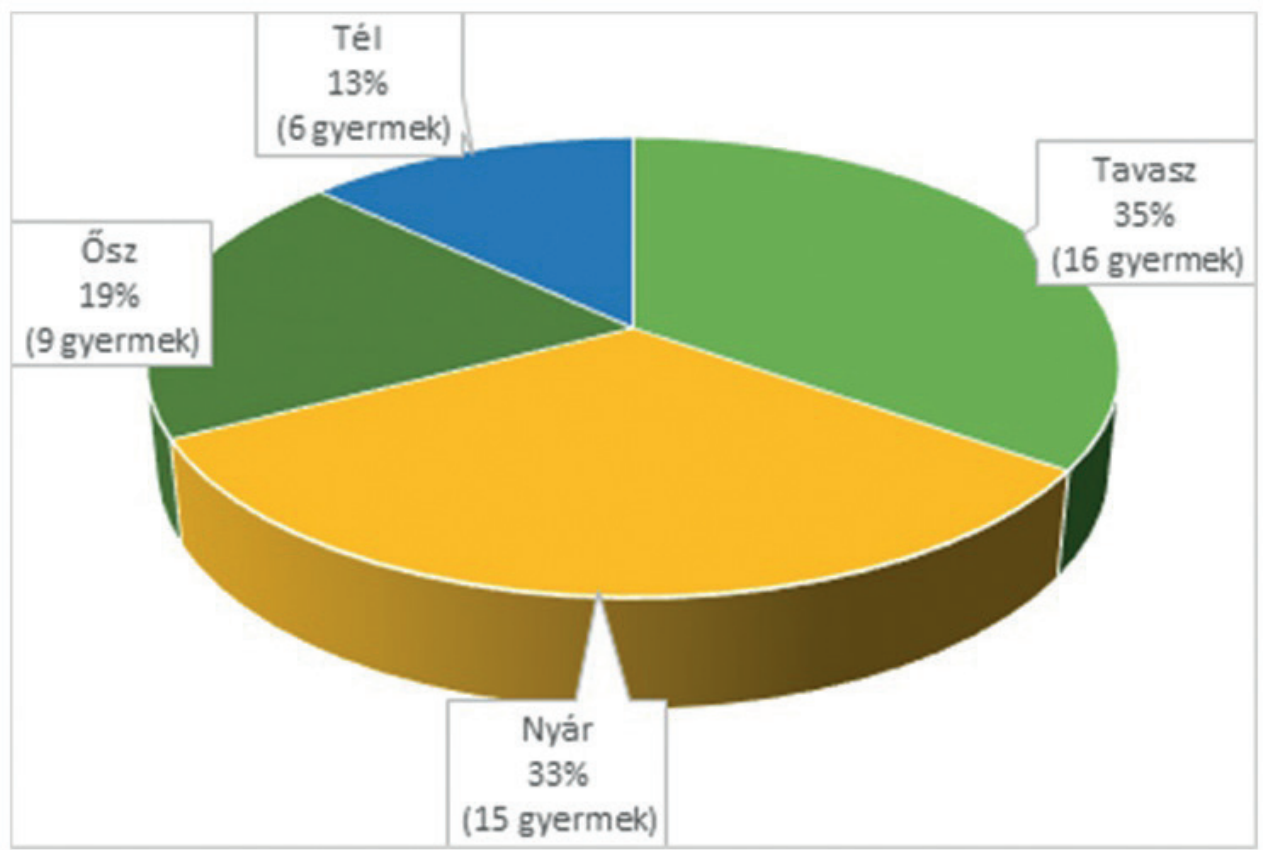

2. ábra

A Baumann III-as típusú supracondylaer humerus törések évszakos megoszlása 


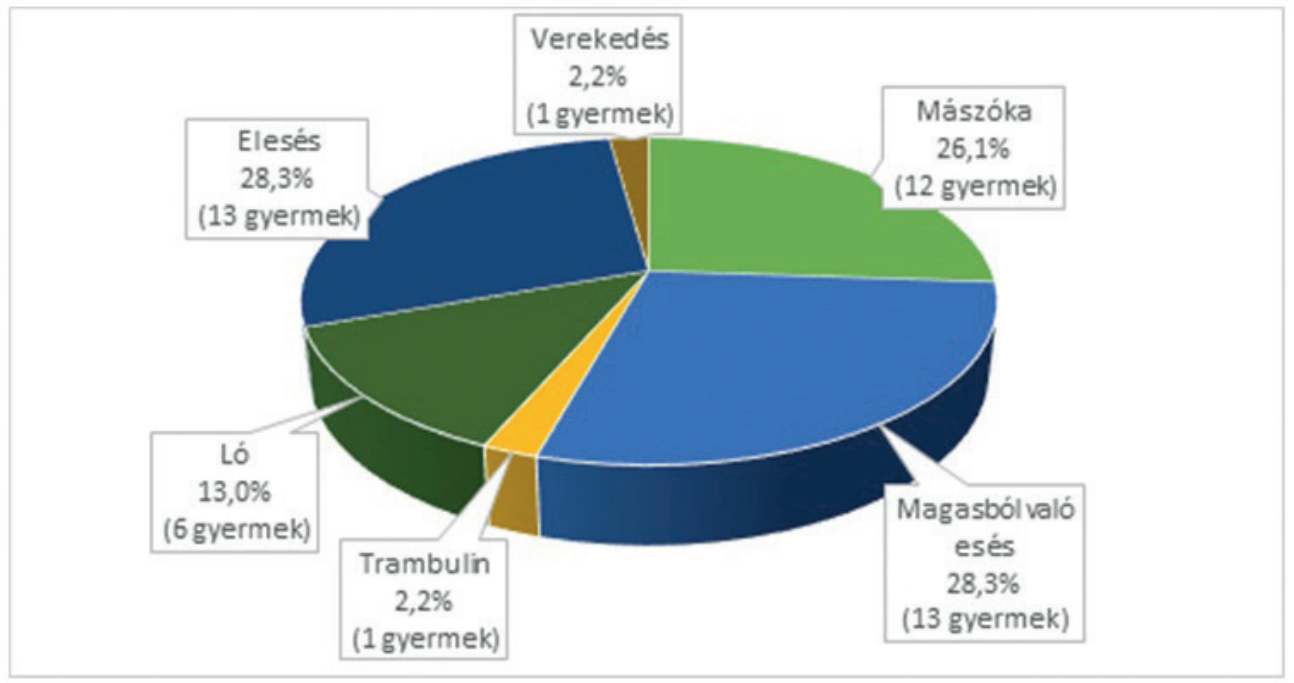

3. ábra

A Baumann III-as típusú SCH törések kialakulásának okai és azok százalékos megoszlása

\section{EREDMÉNYEK}

A vizsgálat 6 éves időtartama alatt a Baumann III-as típusú $\mathrm{SCH}$ törést elszenvedett gyermekek átlagéletkora 8 (3-14) év volt. A Baumann III-as típusú SCH törések kialakulásának okai leggyakrabban magasból való esés, általában játszótéri baleset következménye volt. Ezek közül kiemelendő a mászókáról történő leesés, ami az összes törés 26\%-ának kialakulásáért volt felelős (3. ábra). A törések mechanizmusa szinte minden esetben nyújtott könyökkel való érkezés volt az esés csillapítása céljából.

A 46 Baumann III-as típusú SCH töréssel diagnosztizált gyermek közül 35 gyermeknél találtunk a fizikális vizsgálat alapján megtartott radialis pulzust, míg 11 gyermeknél PPH-t vagy WPH-t. A primeren jól tapintható artéria radialis pulzus a fedett repozíciót követően három gyermek esetében eltúnt, emiatt az ő esetükben és további 8 gyermeknél (PPH és WPH) nyílt feltárást végeztünk (4. ábra).

A keringési zavarok hátterében leggyakrabban előforduló érsérülés az ér megtöretése (4 gyermek) és az ér kompressziója ( 3 gyermek) volt. A nyílt feltárást követően az a. brachialis kompressziója során dekomprimálás, míg megtöretés esetén az ér felszabadítása jelentette a mútéti megoldást. Két gyermeknél a keringési zavar hátterében thrombus képződése állt, mindkét esetben arteriotomiát követően thrombectomiát végeztünk, majd az artériát vénafolttal zártuk, azonban az egyik esetben ezt követően újabb thrombus alakult ki, amely miatt az érszakasz kimetszésére, majd vénagrafttal történő pótlására volt szükség. Egy esetben első lépésként szintén arteriotomiát végeztünk, azonban ebben az esetben a keringési zavar hátterében intima sérülés igazolódott, aminek ellátása során az intima lépcső elvarrását és az ér vénafolttal történő zárását végeztük. Egy másik gyermeknél thrombus kizárása céljából intraoperatív angiográfiás vizsgálat történt, ami thrombust nem igazolt, így a keringészavar hátterében spasmust feltételeztünk. A vizsgálatot követően a keringés ennek megfelelően fokozatosan rendeződött. Egy másik gyermek esetében az a. brachialis teljes szakadását észleltük, a roncsolt arteria csonkok reszekálását követően az érszakasz áthidalására vénagraftot használtunk. 


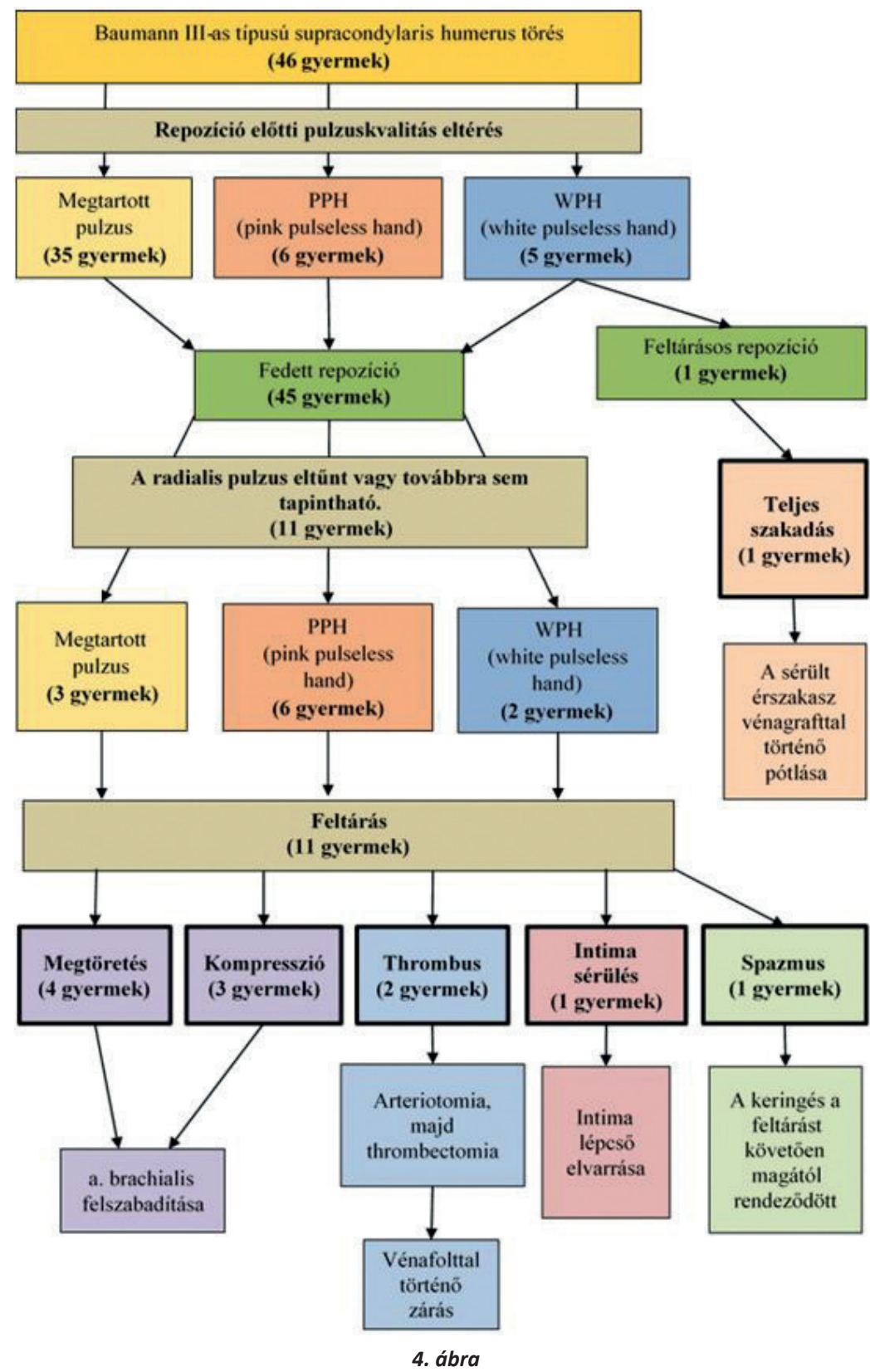

A vizsgálat folyamatábrája 


\section{MEGBESZÉLÉS}

A Baumann III-as típusú törések nemek közti megoszlása egyenlő (50-50\%) volt, ami eltérő a nemzetközi tanulmányokban leírt megoszlásokhoz viszonyítva (10-30\% eltérés a nemek között, a fiúk gyakrabban érintettek) (4). A törések évszakok és életkor szerinti megoszlása a nemzetközi tanulmányokhoz hasonló megoszlást mutatott (7). Az ilyen típusú törések a meleg, száraz évszakok során fordulnak elö leggyakrabban, mert ilyenkor a gyermekek több időt töltenek a szabadban.

A törések ellátását minden esetben az elmozdulás mértéke és az érintett végtag keringése határozza meg. Megtartott radialis pulzus esetén, a törés kíméletes fedett repozíciója javasolt. PPH esetén, a törés kíméletes fedett repozíciója elvégezhető, azonban a retrospektív vizsgálatunk eredményei alapján ezt követően egy gyermeknél sem tért vissza a pulzus, emiatt feltárás történt. Mindezek alapján ezekben az esetekben a primer feltárás megfontolandó. A vizsgálat eredményei alapján a primer feltárás minden olyan esetben mérlegelendő, amikor a pulzuskvalitás csökkent. Fehér, hűvös tapintatú, pulzus nélküli kéz (WPH) vagy a fedett repozíciót követően rosszabbodó végtagi keringés esetén nyílt feltárás a választandó módszer.

Nyílt feltárást követően az ér ellátását az érsérülés típusa határozza meg. Érkompresszió és megtöretés esetén az ér felszabadítása vagy a megtöretés megszúntetése jelent megoldást. Thrombus és intima sérülés esetén arteriotomia, thrombectomia és intima lépcső elvarrása, teljes szakadás esetén a hiányzó és sérült érszakaszok vénagrafttal történő pótlása alkalmazható.

\section{IRODALOM}

1. Ács G.: Supracondylaris törés. In: Gyermektraumatológia. Szerk. Ács G., Hargitai E. Budapest. Medicina. 2001. 635-644. p.

2. Ács G.: A humerus supracondylaris törései. In: Traumatológia. Egyetemi tankönyv. Szerk. Fekete K., Ács G. Budapest. Medicina. 2016. 492. p.

3. Brahmamdam P., Plummer M., Modrall J. G., Megison S. M., Clagett G. P., Valentine R. J.: Hand ischemia associated with elbow trauma in children. J. Vasc. Surg. 2011. 54. (3): 773-778. https://doi.org/10.1016/i.jvs.2011.03.004

4. Kumar V., Singh A.: Fracture supracondylar humerus: A review. J. Clin. Diagn. Res. 2016. 10. (12): RE01-RE06 https://doi.org/10.7860/JCDR/2016/21647.8942

5. Leiblein M., Lustenberger T., Schulz A. K., Schmitz-Rixen T., Marzi I.: Neurovascular complications after supracondylar humerus fractures in children. Trauma Case Rep. 2017. 8: 16-19. https://doi.org/10.1016/i.tcr.2017.01.013

6. Oetgen M. E., Mirick G. E., Atwater L., Lovejoy J. F.: Complications and predictors of need for return to the operating room in the treatment of supracondylar humerus fractures in children. Open Orthop. J. 2015. 9: $139-142$. https://doi.org/10.2174/1874325001509010139

7. Sinikumpu J. J., Pokka T., Hyvönen H., Ruuhela R., Serlo W.: Supracondylar humerus fractures in children: the effect of weather conditions on their risk. Eur. J. Orthop. Surg. Traumatol. 2017. 27. (2): $243-250$. https://doi.org/10.1007/s00590-016-1890-8

8. Wegmann H., Eberl R., Kraus T., Till H., Eder C., Singer G.: The impact of arterial vessel injuries associated with pediatric supracondylar humeral fractures. J. Trauma Acute Care Surg. 2014. 77. (2): $381-385$. https://doi.org/10.1097/TA.0000000000000306

\section{Levelező szerzö: \\ Dr. Józsa Gergö}

PTE KK Gyermekgyógyászati Klinika, Manuális Tanszék, Gyermeksebészeti Osztály

7623 Pécs, József Attila út 7.

dr.jozsa.gergo@gmail.com 